\title{
PERANAN ISTRI NELAYAN DALAM MENINGKATKAN EKONOMI KELUARGA DI KELURAHAN LAPULU KOTA KENDARI PROVINSI SULAWESI TENGGARA
}

\section{THE ROLE OF FISHERMAN'S WIFE IN IMPROVING ECONOMIC CITY FAMILY IN VILLAGE LAPULU KENDARI SOUTHEAST SULAWESI PROVINCE}

\author{
Raodah \\ Balai Pelestarian Nilai Budaya Makassar, Kementerian Pendidikan dan Kebudayaan \\ Jl. Sultan Alauddin Km 7 Makassar \\ Email: raodahtul.janna@yahoo.com \\ Dikirim: 17 Maret 2013; direvisi: 26 April 2013; disetujui: 19 Juni 2013
}

\begin{abstract}
Abstrak
Peranan perempuan di rana ekonomi publik memberi kontribusi yang cukup besar bagi kehidupan keluarga, terutama bagi keluarga yang masih hidup dalam kondisi kemiskinan. Seperti di jumpai pada masyarakat nelayan, yang mata pencahariannya tidak menentu. Ada waktu tertentu dimana nelayan harus melaut dan ada waktu nelayan tidak dapat melaut, karena kondisi cuaca yang tidak memungkinkan. Dalam kondisi yang demikian maka diperlukan peran isteri untuk membantu ekonomi keluarga dengan melakukan pekerjaan di luar rumah (publik). Peran ganda ini dilakoni pula oleh istri-istri nelayan yang ada di Kelurahan Lapulu, mereka melakukan beberapa pekerjaan di sektor perikanan untuk memenuhi kebutuhan ekonomi rumah tangga. Penelitian ini bersifat deskriftif dengan pendekatan kualitatif, metode pengumpulan data dilakukan dengan teknik pengamatan, wawancara dan studi pustaka. Hasil penelitian menunjukkan bahwa istri-istri nelayan di Kelurahan Lapulu selain berperan di rana domestik sebagai ibu rumah tangga yang mengurus suami dan anak-anak, mereka juga meluangkan waktunya untuk membantu suami bekerja sebagai, pengolah ikan asin, pembuatan terasi, berbagai makanan olahan dari rumput laut dan ikan, serta bekerja sebagai buruh di industri pengolahan ikan. Penghasilan yang diperoleh istri-istri nelayan memberi kontribusi yang cukup besar dalam membantu mengatasi biaya kebutuhan rumah tangga nelayan.
\end{abstract}

Kata kunci: isteri nelayan, ekonomi keluarga

\begin{abstract}
The women played an important role in economic public domain in fishermen society of Lapulu Subdistrict, South East Province. It appeared when they lived in poverty condition. The fishermen who merely relied on the sea as source of life would face difficulty in fulfilling his life needs when the climate was bad. The women took economic public when it happened. The research about the role of fishermen's wives in increasing domestic economy in Lapulu Subdistrict of South East Province was descriptive qualitative. Method of collecting data done was observation technique, interview, and library study. Result of research showed that fishermen's wives conducted multiple roles by doing any work in fishery field in order to fulfill their domestic economic needs. They not only played role as housewives who only took care for husband and the children, but also shared time to work in salty fish processing, terasi (condiment made from pounded and fermented shrimp or small fish) making, any food processing made of seaweed, and worked as labor in fish processing industry. Their earnings gave enough contribution for helping in fulfilling domestic cost.
\end{abstract}

Keywords: fishermen's wives, domestic economy

\section{PENDAHULUAN}

Dalam kehidupan sosial, perempuan selalu dinilai sebagai mahkluk yang lemah dibanding lakilaki. Gejala seperti ini menentukan kaum perempuan yang eksistensinya tidak begitu diperhitungkan. Untuk memenuhi kebutuhan materialnya perempuan tergantung kepada lelaki sebagai pencari nafkah. Pembagian peran di sektor publik untuk lelaki, dan sektor domestik untuk perempuan terutama terlihat jelas di lingkungan keluarga ekonomi menengah ke atas. Sedang pada keluarga ekonomi menengah ke bawah pembagian peran kerja berdasarkan sistem patriarkal mengalami perubahan. Kesulitan ekonomi memaksa mereka kaum perempuan dari kelas ekonomi rendah untuk ikut berperan dalam meningkatkan pendapatan keluarganya dengan bekerja di luar sektor domestik. Keterlibatan 
perempuan dalam sektor domestik memang dianggap sebagai peran kodrati sebagai ibu rumah tangga dan keterlibatan mereka disektor publik disebut sebagai peran ganda .

Pada setiap kebudayaan perempuan dan lakilaki diberi peran dan pola tingkah laku yang berbeda untuk saling melengkapi, perbedaan kodrati dari kedua makhluk ini. Winarti dkk (2008) berpendapat bahwa bergesernya perubahan peran atau tepatnya nilai-nilai sosial budaya yang berkembang di masyarakat menjadikan perempuan memiliki tanggungjawab tidak hanya pada sektor domestik, tetapi juga pada sektor publik. Hal ini dipertajam dengan meningkatnya jumlah tenaga kerja perempuan yang kemudian memunculkan peran ganda bagi perempuan itu sendiri. Peran ini mau tidak mau menyebabkan perempuan memiliki jam kerja yang lebih lama, karena disamping perannya sebagai pekerja juga harus menyelesaikan pekerjaan rumah tangga sehari-hari.

Fenomena pemberdayaan perempuan ternyata berperan penting terhadap kelangsungan hidup keluarga, baik berkenaan dengan pembinaan moral anak, maupun pemenuhan kebutuhan ekonomi keluarga. Pola pemanfaatan tenaga kerja pedesaan dalam konteksnya dengan pembagian kerja dalam rumah tangga meliputi baik pekerjaan yang langsung menghasilkan pendapatan uang atau sejenisnya maupun kegiatan pekerjaan rumah tangga. Peranan ibu rumah tangga bukan saja dilihat seberapa besar kontribusi yang telah diberikan dalam menunjang kehidupan sosial ekonomi keluarga, namun peran ibu rumah tangga yang lebih luas dapat pula dilihat dari sumbangsi yang diberikan terhadap lingkungan atau terhadap masyarakat dimana ia bermukim. Peranan perempuan dalam kehidupan keluarga terutama bagi keluarga yang masih hidup dalam kondisi kemiskinan seperti yang banyak kita jumpai pada masyarakat nelayan yang mata pencahariannya tidak menentu, ada waktu dimana para nelayan harus melaut dan ada waktu dimana para nelayan tidak dapat melaut karena kondisi cuaca yang tidak memungkinkan. Dalam kondisi yang demikian maka diperlukan peran isteri untuk membantu ekonomi keluarga dengan melakukan pekerjaan di luar rumah (publik). Kusnadi (2001) berpendapat bahwa, sebagian besar aktivitas perekonomian di kawasan pesisir melibatkan kaum perempuan dan sistem pembagian kerja. Pekerjaan di laut merupakan rana kaum laki-laki, dan perempuan di darat. Peran tersebut telah menempatkan kaum perempuan sebagai penguasa aktivitas ekonomi pesisir. Dampak dari sistem pembagian kerja ini adalah kaum perempuan mendominasi dalam urusan ekonomi rumah tangga dan pengambilan keputusan penting di rumah tangganya

Berkaitan dengan hal tersebut menunjukkan bahwa kaum perempuan sudah banyak terlibat secara aktif dalam membantu ekonomi keluarga. Dari beberapa penelitian telah membuktikan bahwa perempuan mengalokasikan waktunya bukan hanya pada sektor domestik, seperti mengurus rumah tangga, akan tetapi aktivitas perempuan telah merambah ke sektor publik. Kurniawan (2010) menulis tentang Etty Kereway kiprah perempuan Papua yang merintis beberapa usaha kerajinan dengan mengolah hasil limbah alam yang bernilai ekonomi. Dari usaha itu mempekerjakan ratusan ibuibu rumah tangga disekitar tempat tinggalnya di Kabupaten Manokwari. Selanjutnya hasil penelitian Dloyana (2010) berkesimpulan bahwa berkembangnya kawasan industri sepatu di Cibaduyut Bandung membuka peluang bagi kaum perempuan untuk berkiprah, selain disektor domestik sebagai ibu rumah tangga. Dari 1.532 ibu rumah tangga sekitar $68 \%$ yang bekerja sebagai buruh di sentra industri tersebut. Hal yang sama ditemukan juga chusnul (2006) bahwa, Perdagangan batik di pasar-pasar tradisional Yogyakarta sebagian besar dikelola oleh perempuan yang disebut dengan mbok mase, yaitu pedagang batik keliling. Mereka melakukan jual beli bahan dasar batik dan kain batik. Perempuan mengambil peranan $75 \%$ dalam proses produksi dan distribusi dari seluruh aktivitas perusahaan batik milik keluarga. Demikian halnya hasil penelitian Raodah (2010) pada masyarakat nelayan, berpendapat bahwa aktivitas perekonomian masyarakat pesisir sangat ditunjang oleh peran perempuan seperti halnya istri-istri nelayan di kelurahan Panyula kabupaten Bone, yang mengembangkan industri rumah tangga dengan melakukan pengasapan ikan yang disebut bale tapa. Kontribusi pendapat wanita nelayan tersebut sangat membantu ekonomi rumah tangga masyarakat nelayan.

Dari beberapa hasil penelitian yang dikemukakan di atas berkenaan dengan peran perempuan disektor ekonomi publik yang cukup potensial dalam meningkatkan ekonomi keluarga. Kondisi tersebut hampir sama dengan aktivitas perempuan nelayan yang ada di Kelurahan Lapulu Kecamatan Abeli Kota Kendari. Kaum perempuan di daerah ini umumnya yang berstatus sebagai isteri nelayan mempunyai berbagai aktivitas dalam meningkatkan ekonomi keluarga. Pekerjaanpekerjaan tersebut meliputi: Pembuatan ikan asin, terasi, abon ikan serta berbagai makanan dari hasil olahan ikan dan rumput laut, melakukan perdagangan ikan dan sebagian diantaranya bekerja pada industri pengolahan ikan disekitar Kecamatan Abeli. Profesi tersebut telah lama mereka geluti, sebagai salah satu upayah untuk menunjang ekonomi keluarga yang rata-rata suami mereka adalah nelayan.

Berdasarkan fenomena tersebut, penulis merasa tertarik untuk melakukan penelitian yang berkenaan dengan peran ganda istri nelayan di Kelurahan Lapulu. Adapun permasalahan pokok dalam penelitian ini adalah: Bagaimana peran istri nelayan di Kelurahan Lapulu dalam meningkatkan 
ekonomi keluarga. Tujuan yang ingin dicapai dalam kajian ini adalah: (1) untuk mengungkapkan peran istri-istri nelayan dalam aktivitas domestik, sosial dan ekonomi publik, (2) untuk mengetahui faktorfaktor yang mendorong sehingga istri-istri nelayan melakukan peran ganda tersebut, (3) besarnya kontribusi yang diberikan istri nelayan dalam meningkatkan ekonomi keluarga. Selanjutnya hasil penelitian ini akan dijadikan informasi dan publikasi tentang peran ganda istri-istri nelayan di Kelurahan Lapulu, sekaligus memberi masukan kepada pemerintah dalam hal pemberdayaan perempuan di sektor perikanan.

\section{METODE PENELITIAN}

Penelitian ini bersifat deskriptif dengan pendekatan kualitatif yang menggambarkan peran ganda perempuan, khususnya isteri nelayan dalam sektor ekonomi publik dalam meningkatkan ekonomi keluarga. Materi yang menjadi sasaran utama dalam penelitian ini adalah berbagai hal yang berkaitan dengan peran istri-istri nelayan yang bekerja di sektor perikanan yang meliputi pengelolaan ikan asin, pembuatan terasi, produkproduk olahan dari ikan dan rumput laut, dan peran istri nelayan di industri Pengolahan ikan.

Lokasi penelitian adalah di Kelurahan Lapulu Kecamatan Abeli, Kota Kendari Provinsi Sulawesi Tenggara. Masyarakat di Kelurahan Lapulu mayoritas bermata pencaharian sebagai nelayan, karena letak geografis yang berada di wilayah pesisir. Kondisi inilah yang memungkinkan peran perempuan pada keluarga nelayan di kelurahan tersebut dapat melakukan fungsi ganda baik pada sektor domestik maupun publik. Aktivitas ekonomi publik dilakukan bukan hanya untuk kesetaraan gender, akan tetapi terlebih pada kebutuhan hidup untuk menunjang ekonomi keluarga. Berbagai usaha yang dilakukan istri-istri nelayan di Kelurahan Lapulu untuk meningkatkan ekonomi keluarga yang ditunjang oleh kondisi masyarakat dan wilayahnya.

Data yang dikumpulkan dalam penelitian ini berasal dari dua sumber, yaitu Data primer dan data skunder. Data primer diperoleh melalui wawancara dengan beberapa responden informan yang terdiri dari istri-istri nelayan, tokoh-tokoh masyarakat, dan pemerintah setempat yang senantiasa mengupayakan sarana dan prasarana untuk meningkatkan kesejahteraan masyarakat nelayan yang ada di Kelurahan Lapulu. Data sekunder, diperoleh dari sumber arsip-arsip lokal Dinas perikanan dan kelautan, organisasi pemberdayaan wanita, pemerintah setempat dan Badan Pusat Statistik, serta organisasi non pemerintahan (LSM), dan sumber kepustakaan, seperti jurnal, artikel, makalah, tesis, disertasi, dan internet.

\section{HASIL DAN PEMBAHASAN}

\section{Gambaran Kelurahan Lapulu}

Kelurahan Lapulu merupakan salah satu kelurahan dari 13 belas kelurahan yang berada di wilayah pemerintahan Kecamatan Abeli, sebelum dimekarkan Kelurahan Lapulu berada di wlayah Kecamatan Poasia Kota Kendari Provinsi Sulawesi Tenggara. Kelurahan Lapulu terletak di daerah pesisir esturia Teluk Kendari dengan ketinggian \pm 2 meter dari permukaan laut. Merupakan kawasan perkampungan dengan radius atau jarak $\pm 3 \mathrm{~km}$ dari ibukota Kecamatan, dan $\pm 8,4 \mathrm{~km}$ dari Kota Kendari dengan jarak tempuh kurang lebih 20 menit. Untuk menuju ke Kelurahan Lapulu dapat ditempuh melalui dua jalur lewat darat melalui jalan tapak kuda atau bay pass dan jalan poros Andonouhu dengan menggunakan angkutan umum, sedang lewat laut berjarak \pm 640 meter dari pelabuhan rakyat di Kecamatan Kendari Barat melalui jalur Pasar Sentral kota, maupun dari jalur pantai biru Sanggula menggunakan perahu motor jonson.

Kelurahan Lapulu dimekarkan pada tahun 1997 menjadi dua kelurahan yaitu Kelurahan Puday dan Kelurahan Lapulu sendiri. Secara administratif, batas-batas wilayah Kelurahan Lapulu adalah sebagai berikut: Sebelah Utara berbatasan dengan Teluk Kendari, sebelah Selatan berbatasan dengan Kelurahan Abeli, sebelah Barat berbatasan dengan Kelurahan Puday, dan sebelahTimur berbatasan dengan Kelurahan Poasia. Kelurahan Lapulu memiliki luas $\pm 2,1 \mathrm{~km}^{2}$ yang dibagi menjadi $4 \mathrm{RW}$ atau 9 RT. Luas Kelurahan 3,96 \% dari luas Kecamatan Abeli jika dibandingkan dengan luas Kelurahan lainnya, dan menempati peringkat ke 10 dalam hal luas wilayah.

Jumlah penduduk menurut data monografi Kelurahan Lapulu tahun 2011, berjumlah 3.960 jiwa, terdiri dari laki-laki 2006 jiwa dan perempuan 1.954 jiwa yang tergabung dalam $804 \mathrm{kk}$, jumlah penduduk ini tersebar kedalam 4 RW. Penduduk yang bermukim di Keluarahan Lapulu kebanyakan penduduk pendatang sekitar $80 \%$ yang terdiri dari suku Bugis, Makassar, dan Bajo, sedang selebihnya adalah penduduk asli suku Tolaki. Kebanyakan dari suku pendatang ini memdiami wilayah sekitar pesisir pantai Teluk Kendari, mereka pada umumnya bekerja sebagai nelayan. Interaksi antar suku terjalin dengan baik dan mereka sudah kawin mawin, antara suku Bugis Makassar yang kawin dengan orang Bajo dan Orang Tolaki, sehingga budaya mereka sudah berbaur dan menjadi satu kesatuan dalam bermasyarakat. Perempuan suku Bajo, Bugis dan Makassar banyak yang bekerja di sektor industri dan usaha pengolahan hasil laut, mereka sangat aktif membantu suami dalam menambah penghasilan keluarga.

Angka butu huruf penduduk di Kelurahan Lapulu masih cukup tinggi sekitar 25,2 \% dari total penduduk.Sama halnya dengan prosentase penduduk 
tidak tamat SD sebesar 21,7\% . Angka-angka ini hampir setara dengan prosentase jumlah penduduk yang lulus SLTA sebesar 25,4\% yang merupakan angka tertinggi, disusul dengan jumlah penduduk lulus SLTA sebesar 25,3\%. Disisi lain prosentase penduduk yang menamatkan pendidikan tinggi masih terbilang rendah sekitar $0,7 \%$ untuk lulusan D1, 0,1 $\%$ dan lulusan D2 dan 2,6\% untuk lulusan S1.

Mayoritas warganya bermata pencaharian sebagai nelayan, mereka terdiri dari nelayan pemilik, buruh nelayan, pembudidayaan ikan dan organisme laut lainnya, pedagang ikan, pengolah ikan (industri ikan kering), supplier faktor sarana produksi perikanan (industri kapal rakyat misalnya). Dalam non perikanan, masyarakat pesisir bisa terdiri dari penjual jasa pariwisata, penjual jasa transportasi (kelompok jonson), serta kelompok masyarakat lainnya yang memanfaatkan sumberdaya non hayati laut dan pesisir untuk menyokong kehidupannya. Penduduk Kelurahan Lapulu mayoritas beragama Islam sekitar $95,19 \%$ dan selebihnya adalah penduduk beragama Kristen sebesar 4,81\%. Masyarakat pendatang yang bermukim di Kelurahan Lapulu kesemuanya beragama Islam, sementara sebagian kecil masyarakat suku Tolaki yang beragama Kristen. Untuk mengakomadasi kebutuhan masyarakat dalam beribadah, maka tersedia tempat ibadah berupa dua bangunan Mesjid satu Musholla, dan satu gereja.

\section{Peran Domestik dan Sosial}

Di dalam kehidupan keluarga, perempuan sebagai istri memainkan peran sebagai makhluk sosial yang berhubungan mesra dengan suaminya, sebagai teman hidup dan ibu yang penuh kasih sayang terhadap anak-anaknya. Sesuai pernyataan Baker (dalam Fadliah 2011) bahwa menjadi seorang istri, ibu rumah tangga adalah pekerjaan mulia, suatu peran yang harus ditekuni dan dijalani secara profesional. Peran istri untuk urusan domestik bukan sekedar kewajiban, melainkan sudah kodratnya dalam kehidupan rumah tangga, sementara suami berperan sebagai kepala rumah tangga yang menafkahi seluruh kebutuhan istri dan anak-anaknya. Demikian halnya pada rumah tangga nelayan, pengaturan atau pengolahan rumah tangga merupakan tugas utama para istri, kegiatan ini seolah-olah tidak mengenal waktu dalam pelaksanaannya. Tugas itu berkaitan dengan penyiapan makan dan minum bagi segenap anggota keluarga, mengasuh anak, mendidik, menjaga dan mengarahkan anak-anak terutama bagi yang belum dewasa mengurus, membersihkan dan membenahi perabot rumah tangga, mencuci dan merapikan pakaian segenap anggota keluarga. Istri-istri nelayan di Kelurahan Lapulu tetap menempatkan peran domestik atau reproduktif sebagai peran utama dalam keluarga. Peran seorang wanita yang telah menikah dalam keluarganya sebagai isteri atau ibu dituntut untuk mengurus suami dan anak-anaknya, peran tersebut tidak terlepas dari aktivitas mereka sehari-hari.

Karakteristik pekerjaan suami sebagai nelayan yang harus meninggalkan rumah dalam jangka waktu tertentu, membuat peran pengambilan keputusan banyak diambil alih oleh para istri. Walaupun kadang mereka berkonsultasi kepada suami atas keputusan-keputusan yang akan atau telah diambil, pada akhirnya istrilah yang melakukan pengambilan keputusan tersebut. Keputusan yang diambil alih termasuk keputusan internal keluarga, maupun keputusan-keputusan berhubungan dengan pihak luar. Suami lebih banyak berada di lingkungan laut dan fokus pada kegiatan mencari ikan sedang istri lebih banyak berada dilingkungan keluarga dan luar, sehingga pengambilan keputusan, lebih dominan dilakukan istri.

Dalam urusan keuangan rumah tangga pada umumnya pengelolaannya dibebankan pada istri, terutama dalam mengatur pengeluaran pembiayaan rumah tangga. Bentuk-bentuk pengeluaran masih bersifat kebutuhan mendasar misalnya untuk komsumsi keluarga, perlengkapan produksi ekonomi dan biaya pendidikan anak-anak. Sedang pengeluaran untuk kebutuhan pakaian, perabot, kesehatan dan biaya sosial lainnya merupakan pengeluaran yang tidak menentu dan masih dapat ditangguhkan apabila kebutuhan ini tidak terlalu mendesak. Seperti yang diutarakan ibu Darti (32 tahun), bahwa pengambilan keputusan dalam urusan keuangan diserahkan kepadanya, karena suami waktunya lebih banyak di laut dan kembali sekali dalam sebulan. Sehingga pengambilan keputusan untuk urusan keuangan dan rumah tangga, seperti penentuan biaya sekolah anak-anak, pembelian perabot, dana sosial dan sebagainya diserahkan sepenuhnya kepada saya (wawancara 9 pebruari 2012).

Sebagai istri nelayan dimana pendapatan suami tidak menentu tergantung kemurahan alam, maka keputusan-keputusan yang diambil mengharuskan memiliki intuisi dan pengetahuan akan resiko dari keputusan yang diambil. Kebanyakan keputusan yang berhubungan dengan keluarga mereka lakukan secara langsung karena desakan waktu. Keputusan keuangan juga lebih banyak dilakukan para istri mengingat merekalah pengelola keuangan rumah tangga. Apabila kekurangan dana maka istri yang menanggulangi dari penghasilannya bekerja. Musyawarah antara istri dan suami dilakukan dalam pengambilan keputusan terutama untuk hal yang bersifat khusus. Hampir seluruh informan menjawab bahwa penghasilan suami sebagai nelayan seluruhnya diberikan pada istri untuk di kelolah

Peran istri nelayan di Kelurahan Lapulu bukan hanya terbatas pada aktivitas domestik dan ekonomi publik, mereka juga masih meluangkan waktu untuk aktif dalam kegiatan-kegiatan sosial kemasyarakatan. Kegiatan tersebut berupa pelatihan keterampilan ataupun penyuluhan yang diadakan oleh ibu-ibu 
PKK di Kelurahan Lapulu. Selain kegiatan tersebut masih terdapat kegiatan-kegiatan lainnya seperti arisan dan pengajian kelompok majelis Ta'lim. Secara umum pelaksanaan kegiatan tersebut terkoordinir dengan baik. Antusiasme dari kaum ibu pun cukup banyak mengikuti kegiatan-kegiatan tersebut. Mereka terbentuk dalam kelompok kerja yang dibentuk oleh ibu-ibu nelayan, menurut Ibu Maulida (35 tahun) yang bertugas sebagai penyuluh perikanan di Kecamatan Abeli mengatakan bahwa di Kelurahan Lapulu sudah banyak terbentuk kelompok wanita-wanita nelayan yang beranggotakan sekitar 15 sampai 20 orang dalam satu kelompok, dengan melakukan kegiatan industri rumah tangga berupa pengolahan hasil perikanan yang siap dipasarkan di masyarakat. Kegiatan ini dirasakan sangat membantu untuk meningkatkan kesejahteraan keluarga (wawancara 10 Pebruari 2012)

Dalam kelompok PKK, ibu-ibu nelayan diajarkan berbagai macam keterampilan utamanya yang berhubungan dengan hasil perikanan dan dan biota laut, misalnya pengolahan ikan asin, pembuatan bakso ikan, abon ikan, keripik rumput laut dan berbagai olahan menu yang terbuat dari rumput laut. Aktivitas ibu-ibu nelayan dalam kegiatan sosial ini sudah mendapat apresiasi dari pemerintah provinsi bahkan sampai tingkat nasional dalam berbagai perlombaan yang berkaitan dengan pengolahan hasil laut. Kelompok wanita nelayan di Kelurahan Lapulu yang senantiasa mengikuti perlombaan adalah kelompok wanita nelayan Bajo Indah yang diketuai ibu Linda (32 thn) yang telah mengikuti berbagai perlombaan dan beberapa kali mendapat penghargaan.

Keberhasilan kelompok-kelompok wanita nelayan di Kelurahan Lapulu dalam berprestasi tidak terlepas dari keterlibatan pemerintah dalam berbagai program pemberdayaan masyarakat yang dikelolah masyarakat melalui BKM (Badan Keswadayaan Masyarakat) misalnya PNPM (Program Nasional Pemberdayaan masyarakat) Mandiri. Sesuai dengan kondisi masyarakat di Kelurahan Lapulu, yang bergerak di bidang perikanan dan kelautan melalui tiga komponen yaitu Pengembangan Usaha Mina Pedesaan (PUMP) Perikanan Tangkap, Perikanan Budidaya dan Pengolahan dan Pemasaran Hasil Perikanan. Program pemerintah ini sangat membantu masyarakat nelayan di Kelurahan Lapulu.

Dalam kegiatan keagamaan ibu-ibu nelayan juga sangat aktif melakukan pengajian yang dilaksanakan oleh majelis taklim di Kelurahan Lapulu. Pengajian ini rutin dilaksanakan setiap bulan dirangkaiakan pula dengan arisan yang mengambil tempat di Mesjid Lapulu. Anggota pengajian ini bukan saja dari ibu-ibu nelayan, akan tetapi seluruh masyarakat yang berdomisili di Kelurahan Lapulu. Kelompok majelis Taklim di Kelurahan Lapulu mempunyai berbagai program kegiatan misalnya membuka pengajian untuk anak-anak yang tergabung dalam TPA/TKA dan dewasa melalui metode Qiraah untuk ibu-ibu yang buta aksara AlQur'an, mengunjungi apabila anggota yang sakit atau meninggal dengan menyelenggarakan ta'siyah dan membantu penyelenggaraan jenazah. Kegiatan kerohanian ini disamping menambah pengetahuan ibu-ibu dalam ilmu agama juga dapat berorganisasi, dan bersosialisasi dalam masyarakat.

\section{Peran Istri Nelayan pada Sektor Ekonomi Publik}

Masyarakat nelayan di Kelurahan Lapulu di Kecamatan Abeli, merupakan salah satu golongan sosial yang kelangsungan hidupnya ditopang oleh kemampuannya mengelolah sumberdaya perikanan yang tersedia di lingkungannya. Pembagian peran yang sejajar khususnya dari aspek ekonomi perikanan dimana perempuan nelayan yang mengurusi pasca panen yang meliputi pengolahan, pengawetan dan pemasaran, sementara pria pada aspek produksi melalui kegiatan penangkapan ikan dapat menjadi salah satu cara untuk mendorong partisipasi wanita lebih baik. Sebagai nelayan kecil atau buruh nelayan penghasilan dari kegiatan melaut bersifat spekulatif dan tidak tentu, untuk memenuhi kebutuhan hidup sehari-hari, maka kaum perempuan pesisir atau isteri nelayan mengambil peranan yang sangat penting.

Perempuan nelayan merupakan salah satu komponen yang sangat penting dalam pembangunan pesisir karena posisisnya yang strategis dalam kegiatan berbasis perikanan dan kelautan sebagai pedagang pengecer, pengumpul ikan, pedagang besar, buruh upahan, maupun tenaga pengolah hasil perikanan. Keterbatasan ekonomi keluargalah yang menuntut wanita nelayan termasuk anak-anak mereka bekerja di daerah pesisir. Bahwa istri nelayan harus bekerja dengan motivasi utama mencari tambahan penghasilan dalam usaha memenuhi kebutuhan ekonomi rumah tangga mereka yang sepertinya sudah menjadi keharusan. Kondisi ekonomi keluarga dimana jumlah kebutuhan yang semakin meningkat dengan bertambahnya anggota keluarga yang memerlukan berbagai kebutuhan baik bersifat primer maupun sekunder. Sementara penghasilan suami yang hanya sebagai nelayan kecil sangat tidak mencukupi untuk memenuhi kebutuhan ekonomi keluarga.

Sudah menjadi gejala umum jika isteri nelayan harus bekerja demi memperoleh pendapatan tambahan untuk mencukupi kebutuhan sosial ekonomi rumah tangganya. Istri nelayan bekerja lebih kepada alasan karena kebutuhan ekonomi, bukan berdasarkan pada kesetaraan gender. Maksudnya adalah, bahwa istri-istri nelayan bekerja mencari nafkah untuk memenuhi kebutuhan ekonomi keluraga karena pendapatan suami masih rendah dan tidak mencukupi kebutuhan ekonomi keluarga, sehingga menyebabkan tekanan ekonomi keluarga. Sebagai nelayan penghasilan suami hanya mengandalkan hasil tangkapan ikan dari aktivitas bekerja di laut, dimana unsur gambling antara 
mendapat tangkapan dengan tidak mendapat tangkapan ikan selalu ada. Sedang untuk nelayan yang bekerja pada bos/pemilik kapal, mereka harus membagi keuntungan dari hasil tangkapan yang di dapat selama berlayar dengan lama waktu sekitar 20 hari atau lebih.

Perempuan nelayan di Kelurahan Lapulu pada umumnya mempunyai aktivitas di sektor ekonomi publik dan sangat giat membantu meningkatkan ekonomi keluarga. Berbagai usaha yang dikelolah oleh istri-istri nelayan seperti membuat ikan kering, terasi, bakso ikan dan berdagang ikan asin. Bagi mereka yang memiliki kemampuan modal usaha yang cukup, dapat mengembangkan usaha ekonomi secara mandiri, dengan menjadi pedagang pengumpul ikan asin, dan jika tidak isteri nelayan akan menjadi tenaga kerja lepas maupun tetap di perusahaan industri perikanan yang terdapat di sekitar ke Lurahan Lapulu, atau ke unit-unit usaha yang dikelola orang lain. Adapun Aktivitas-aktivitas di rana publik yang dilakukan istri-istri nelayan di Kelurahan Lapulu Kecamatan Abeli dalam meningkatkan ekonomi keluarga adalah:

\section{Usaha Pengolahan Ikan dan Rumput laut}

Aktivitas istri-istri nelayan dalam pengolahan ikan dan rumput laut di Kelurahan Lapulu pada umumnya dilakukan secara bekelompok yang tergabung dalam kelompok wanita nelayan. Kegiatan ini dilakukan setelah aktivitas domestik dalam urusan rumah tangga selesai, sehingga tidak mengganggu peran mereka sebagai ibu rumah tangga dalam mengurus suami dan anak. Mereka bekerja sesuai ketersediaan bahan yang akan diolah, sehingga tidak setiap hari mereka harus bekerja. Ada beberapa kelompok wanita nelayan di Kelurahan Lapulu yang melakukan pengolahan ikan dan rumput laut yaitu: Kelompok wanita nelayan Bajo Indah, Kelompok wanita nelayan sumber rejeki, kelompok wanita nelayan Tenggiri dan kelompok wanita nelayan Maju Bersama.

Kelompok wanita nelayan ini beranggotakan istri-istri nelayan, dimana setiap kelompok terdiri atas 10 sampai 15 orang dengan usia produktif 30 sampai 60 tahun. Mereka bekerja sama dalam usaha pengolahan ikan yang menghasilkan berbagai produk, misalnya pengolahan ikan asin, bakso ikan, otak-otak ikan, abon ikan, terasi dan berbagai makanan yang terbuat dari rumput laut. Adapun jenis usaha yang dilakukan kelompok wanita nelayan sebagai berikut : 1). Kelompok wanita nelayan Bajo Indah melakukan usaha pengolahan ikan asin dan terasi, 2) Kelompok wanita nelayan Sumber Rejeki melakukan usaha pengolahan ikan asin dan makanan olahan dari ikan, 3) Kelompok wanita nelayan Tenggiri melakukan usaha pengolahan ikan asin dan berbagai makanan yang terbuat dari rumput laut. 4) Kelompok wanita nelayan Maju bersama melakukan usaha makanan yang terbuat dari rumput laut, dan 5)
Kelompok wanita nelayan pesisir khusus melakukan usaha pembuatan abon ikan,dan abon udang.

Walaupun setiap kelompok mempunyai spesifikasi usaha, tapi pada umumnya mereka mempunyai usaha yaitu pengolahan ikan asin, karena pengolahan ikan asin merupakan produksi utama masyarakat nelayan di Kelurahan Lapulu. Pengolahan ikan asin dilakukan dengan cara tradisional dengan peralatan sederhana dimana ikan yang akan diasini terlebih dahulu dibersihkan dengan membelah ikan lalu mengeluarkan isi perut ikan, kemudian dicuci sampai bersih, selanjutnya ikan diberi garam dan didiamkan selama satu malam agar garamnya meresap, kesesokan harinya ikan baru dijemur. Pengeringan berlangsung sekitar 2 sampai 3 hari apabila cuaca cerah. Banyaknya ikan yang dikelolah dalam sehari biasanya berkisar antara 100 sampai $200 \mathrm{~kg}$, pengelolaan ikan sangat bergantung pada musim. Pada musim penangkapan ikan dan cuaca cerah maka pengolahan ikan asin jumlahnya akan meningkat, sementara apabila musim penghujan aktivitas kelompok ini biasanya berhenti untuk sementara. Harga jual ikan asin berada dikisaran Rp.60.000 sampai Rp.65.000,- perkilogram apabila di jual langsung ke konsumen, kalau dijual melalui perantara atau di pasarkan ke supermaket maka harganya lebih rendah, sekitar Rp. 55.000 perkilogram. Jenis-jenis ikan yang diasinkan misalnya ikan sunu, ikan teri, ikan katamba dan ikan cakalang. Tapi lebih dominan yang dibuat ikan asin adalah ikan jenis sunu. Bagi nelayan yang melakukan penangkapan ikan sunu menjualnya dengan dua cara, yang masih hidup biasanya langsung dijual keperusahaan-perusahaan pengekspor ikan, sedang ikan sunu yang sudah mati diolah menjadi ikan asin.

Pembuatan terasi udang, pengolahannya dilakukan dengan cara dan peralatan yang sederhana yaitu dengan membersihkan udang terlebih dahulu, lalu dikukus, selanjutnya udang ditumbuk sampai halus dan dibentuk menjadi terasi padat yang dikenal dengan terasi basah. Untuk terasi bubuk kering dilakukan dengan cara mengukus terasi padat tadi kemudian disangrai sampai kering sampai menjadi bubuk terasi, selanjutnya di kemas dalam bungkus plastik untuk di jual. Harga jual terasi padat untuk ukuran $1 \mathrm{~kg}$ sebesar Rp. 55.000,-,sampai Rp.60.000 dan pemasaranya di lakukan di pasar-pasar sekitar Kelurahan Lapulu dan di Kota Kendari. Menurut ibu Linda (33 tahun) ketua kelompok wanita nelayan Bajo Indah, untuk produksi terasi udang bubuk saat ini, masih dilakukan uji coba kemasannya di Jakarta untuk mendapatkan kemasan terasi yang mempunyai standar nasional (wawancara 13 Peberuari 2012).

Pembuatan abon ikan yang bahannya bakunya dari ikan tuna baby dilakukan dengan cara ikan dikukus, setelah matang lalu diangin-anginkan selanjutnya dihaluskan dan diberi bumbu berupa bawang putih, bawang merah, lengkuas, sereh, gula merah. Setelah bumbu tercampur dengan ikan yang 
telah dihaluskan kemudian adonan ikan dicampur santan kelapa dan dimasak sampai kering, demikian pula untuk pembuatan abon udang dilakukan dengan cara yang sama. Menurut ibu Maulida (40 tahun) penyuluh perikanan di Kecamatan Abeli, mengatakan ada beberapa kelompok wanita nelayan yang melakukan usaha rumah tangga (home industry) pengolahan abon ikan dan udang, yang tempat pengolahannya masih bersatu dengan dapur rumah tangga. Sementara persyaratan untuk mendapatkan produksi pengolahan abon berstandar nasional tempat pengolahannya harus terpisah dengan dapur, dan kemasan yang digunakan mempunyai bahan almunium foil, aqun preses, uji kadaluarsa dan terdapat lebel halal. Karena persyaratan tersebut belum sepunuhnya di penuhi, maka produksi abon ikan dan udang ini masih terbatas untuk pasaran lokal saja (wawancara 15 pebruari 2012)

Pada kelompok wanita nelayan yang melakukan pengolahan rumput laut untuk produk makanan seperti kripik, es rumput laut dan sirup rumput laut. Kripik rumput laut dilakukan dengan cara, rumput laut terlebih dahulu dijemur sebelum direndam selama 3 malam, setelah dicuci bersih lalu diblender. Adonan rumput laut yang telah diblender kemudian dicampur terigu, gula, garam dan penyedap rasa selanjutnya dibentuk sesuai selera kemudian digoreng. Kripik rumput laut ini sangat digemari konsumen mulai dari anak-anak sampai dewasa. Sedang pada pembuatan sirup rumput laut diolah dengan mencampurkan gula dan aroma sesuai selera. Produk makanan dari rumput laut ini pemasarannya masih terbatas pada kalangan masyarakat di sekitar kota Kendari

Usaha pengolahan ikan yang dilakukan kelompok wanita nelayan yang telah menghasilkan berbagai produk makanan merupakan salah satu usaha yang memberi kontribusi yang cukup besar untuk meningkatkan pendapatan keluarga. Dalam setiap kelompok pengaturan keuangan dari usaha yang meliputi upah dan gaji anggota diatur oleh bendahara kelompok atas persetujuan semua anggota dan dibayarkan sesuai dengan kehadiran mereka bekerja dalam kelompok usaha. Mereka bekerja bersama-sama mulai dari pengolahan sampai pengemasan, sehingga pembagian pekerjaan merata untuk setiap anggota.

Kelompok wanita nelayan Bajo Indah, merupakan salah satu kelompok wanita nelayan di Kelurahan Lapulu yang sangat aktif melakukan pengolahan ikan terutama untuk pembuatan ikan asin. Kelompok ini terbentuk sejak tahun 1997 dan selalu mengikuti berbagai perlombaan yang berkaitan dengan pengolahan hasil laut dan beberapa kali mendapatkan penghargaan dari pemerintah provinsi Sulawesi Tenggara. Untuk pengembangan dan pembinaan wanita nelayan di Kelurahan Lapulu, beberapa kelompok wanita nelayan telah diikutsertakan berbagai pelatihan diantaranya:
Pengolahan dan pemasaran ikan, pengemasan produk, manajemen usaha dan dispersifikasi olahan ikan; abon, nuget, otak-otak, dan ikan asap. Setiap pelatihan diikuti oleh ketua kelompok atau yang mewakili kelompoknya, hasilnya disosialisasikan atau diajarkan pula kepada anggotanya, untuk meningkatkan sumber daya manusia anggota kelompok

\section{Usaha Penjualan Ikan}

Selain melakukan usaha produk hasil olahan ikan, istri-istri nelayan di Kelurahan Lapulu menekuni pula usaha penjualan ikan baik dalam bentuk segar maupun ikan kering (asin). Wanitawanita nelayan yang memiliki modal usaha, melakukan perdagangan ikan segar dengan cara membeli ikan dari nelayan kemudian menjualnya ke pasar-pasar atau di jajakan keliling kampung. Sedang bagi pedagang ikan asin mereka membeli ke pengoleloh usaha ikan asin baik yang ada di sekitar Kelurahan Lapulu, maupun di luar wilayah Lapulu. Seperti yang di lakukan Ibu Siti Fatima (56 tahun) adalah salah satu wanita nelayan penjual ikan asin yang memulai usahanya sejak tahun 1998. Ia membeli ikan asin di Tinanggea, sekitar $100 \mathrm{~km}$ dari Lapulu, kemudian menjualnya ke pasar-pasar di Kota Kendari.

Aktivitas pembuatan ikan asin banyak pula dilakukan istri-istri nelayan secara kecil-kecilan yaitu dengan mengolah hasil tangkapan suami mereka yang tidak terjual untuk dijadikan ikan asin dan menjual kepada konsumen atau pedagang pengumpul yang mendatangi rumah-rumah pembuat ikan asin. Pengolahan ikan asin lebih banyak ditekuni masyarakat nelayan di Kelurahan Lapulu, karena harga jualnya lebih mahal dari pada ikan segar, apalagi untuk jenis ikan sunu dan katambak. Modal berjualan ikan asin berkisar antara Rp.500.000,sampai Rp. 700.000,- Harga ikan sunu segar untuk 20 kg sekitar Rp. 300.000,- Tapi setelah di keringkan ikan akan menyusut sekitar 4 sampai $5 \mathrm{~kg}$. Walaupun menyusut setelah di jemur akan tetapi harga ikan sunu masih menguntungkan apabila di jadikan ikan asin. Harga jual per kilo ikan sunu kwalitas bagus sekitar Rp.65.000 sampai Rp. $70.000 / \mathrm{kg}$.

\section{Peran istri nelayan di Industri Pengolahan Ikan}

Partisipasi peran wanita dalam era industrialisasi, dimana sektor industri menjadi motor pembangunan sangat diperlukan adanya tenaga kerja yang merupakan salah satu input dalam proses produksi. Sumbangan wanita dalam pembangunan ekonomi terlihat dari kecenderungan partisipasi wanita dalam angkatan kerja. Sebagai salah satu indikator, partisipasi dalam bidang ekonomi ditunjukkan dari laju peningkatan partisipasi wanita dalam angkatan kerja lebih cepat dari peningkatan laju partisipasi pria. Peningkatan laju partisipasi 
ditunjukkan pula pada aktivitas ekonomi publik yang dilakukan oleh istri-istri nelayan di Kelurahan Lapulu, yang bekerja di sektor industri pengolahan ikan. Wanita-wanita nelayan yang berstatus sebagai buruh pabrik yang bekerja dengan upah harian dan bulanan. Ada beberapa industri pengolahan ikan yang mempekerjakan warga di sekitar Lapulu diantaranya perusahaan Supratuna, MJL, PT Cilacap, PT Andika, PT Bung, PT Amo dan Yanagi (perusahaan asing). Pada umumnya perusahaanperusahaan ini melakukan usaha ikan dan udang beku dan hasil laut lainnya. Menurut keterangan dari Lurah Lapulu bahwa, sebagian besar wanita-wanita nelayan yang bekerja di industri pengolahan ikan adalah warga kelurahan Lapulu, aktivitas ini sudah berlangsung lama sejak tahun 1991 ketika disekitar pantai Kendari tepatnya di Kelurahan Puday dibangun industri-industri pengolahan ikan. Keberadaan perusahaan - perusahaan ini juga memberi peluang dalam memasarkan hasil tangkapan nelayan yang mencari ikan di sekitar peraiaran pantai Sulawesi Tenggara. Banyak pula nelayan-nelayan yang datang dari luar mensuplai ikan di Industri pengolahan ikan ini misalnya nelayan-nelayan Mandar dan nelayan Bugis dari perairan Teluk Bone.

Pekerjaan sebagai buruh pengolah ikan dan hasil laut lainnya pada perusahaan tersebut, sangat diminati oleh sebagian istri nelayan karena mereka mendapat penghasilan yang cukup memadai untuk menopang ekonomi keluarga seperti yang dilakukan Ibu Darti (32 tahun), yang sehari-hari bekerja di industri pengolahan ikan, mulai dari jam 8.00 sampai jam 16.00 sore. Pekerjaan yang dilakukan adalah membersihkan ikan-ikan kemudian di bekukan, ia mendapat upah perhari sekitar Rp. 43.100, dan apabila lembur ia mendapat tambahan upah Rp.6.800 perjam.

Peran istri nelayan untuk menambah penghasilan keluarga dengan bekerja di industri pengolahan ikan menjadi salah satu pilihan aktivitas ekonomi publik warga masyarakat di Kelurahan Lapulu. Kerena pekerjaan ini selain memberi upah tetap sesuai kehadiran mereka dalam bekerja, bagi mereka yang sudah menjadi pegawai tetap mendapat tunjangan, misalnya tunjangan hari Raya (THR) yang diberikan perusahaan menjelang hari raya Idul Fitri, Jamsostek untuk seluruh keluarga, selain itu mereka mendapat jatah makan apabila mereka lembur. Menurut Muliana (33 tahun) yang berstatus sebagai istri pappalele yang telah bekerja di PT Sultra Tuna selama 4 tahun, lebih menyukai bekerja sebagai buruh industri dari pada mengolah ikan hasil tangkapan suaminya sebagai nelayan. Menurutnya bekerja sebagai buruh perusahaan pendapatannya sudah tetap asalkan kita hadir dan mulai bekerja sesuai jam kerja perusahaan, boleh lembur kalau suami mengizinkan.

Aktivitas istri-istri nelayan yang bekerja disektor industri, menempatkan peran wanita sebagai gender dalam persamaan hak untuk mendapat perlindungan dari perusahaan sebagai tenaga kerja yang mempunyai hak-hak dan kewajiwaban. Pemberian cuti melahirkan dan cuti haid adalah satu bentuk kepedulian perusahaan untuk menghargai harkat wanita sebagai tenaga kerja yang dilindungi undang-undang ketenagakerjaan. Berbagai keuntungan yang dirasakan sebagian wanita nelayan yang bekerja disektor industri, walaupun harus bekerja sehari penuh dan meninggalkan keluarga, akan tetapi ada penghasilan tetap yang akan diperoleh setiap bulan. Pekerjaan sebagai buruh industri tidak serta merta meninggalkan tugas tradisi mereka sebagai ibu rumah tangga yang mengurus suami dan anak, akan tetapi mereka sudah dapat mengatur waktu agar dapat berperan ganda baik dalam aktivitas domestik maupun aktivitas ekonomi publik untuk membantu ekonomi keluarga. Kegiatan sebagai buruh perusahaan memberi peluang istri-istri nelayan di Kelurahan Lapulu untuk mendapatkan penghasilan sendiri, tidak hanya mengandalkan pendapatan suami sebagai nelayan, yang penghasilannya tidak menentu (wawancara Asriani, Pebruari 2011).

\section{Faktor-Faktor yang Mempengaruhi Isteri Nelayan Terlibat dalam Sektor Ekonomi publik.}

Selain faktor pendapatan suami yang rendah alasan lain istri bekerja karena ingin memiliki uang sendiri dan dapat mengambil keputusan sendiri tanpa berembuk dengan suami serta dapat mengaktualisasikan diri. Menurut Margaret $\mathrm{M}$. Poloma (dalam Fadlia, 2011) menyatakan bahwa seorang bekerja mempunyai ciri-ciri ekonomi, psikologi dan sosial. Secara ekonomi manusia akan memperoleh nafkah untuk hidup memenuhi berbagai sarana penunjang hidup lainnya, dari segi psikologi bekerja seseorang akan mengalami kepuasaan serta memberi harga diri, perasaan aman dan kesempatan untuk mengaktualisasikan diri. Secara sosial bahwa bekerja tidak sekedar bertahan hidup tetapi juga memerlukan kerukunan tetangga serta tolong menolong dalam masyarakat. Ada beberapa faktor yang mempengaruhi istri nelayan untuk bekerja pada sektor ekonomi publik yaitu :

\section{a. Rendahnya Pendapatan Nelayan}

Faktor-faktor penyebab terjadi permasalahan gender adalah tingkat pendapatan suami yang masih rendah menyebabkan tekanan ekonomi keluarga. Tingkat pendapatan yang rendah menjadikan para nelayan hanya terfokus pada upaya untuk memenuhi kebutuhan dasar. Hal ini terjadi karena laki-laki kurang berusaha/kurang mendapat akses dalam memenuhi kebutuhan dasar keluarga, tingkat pendidikan dan keterampilan yang rendah, kondisi sosial budaya yang tidak berpihak kepada akses perempuan. Sebagai istri nelayan, mereka tidak dapat berpangku tangan sambil menunggu suami pulang. Waktu yang ada diisi dengan kegiatan yang bersifat 
produktif, penghasilan suami yang belum mencukupi untuk memenuhi kebutuhan hidup sehari-hari, diperlukan penunjang lewat peran istri nelayan untuk berkipra di ekonomi publik. Menurut pendapat dari beberapa istri nelayan yang bekerja melakukan berbagai aktivitas produktif dalam pengolahan ikan, perdagangan ikan, sebagai buruh pada industri pengolahan ikan mengatakan bahwa: Penghasilan suami mereka sebagai nelayan terkadang tidak mencukupi untuk membiaya kebutuhan rumah tangga, apalagi pada musim tertentu mereka tidak melaut sehingga otomatis mereka tidak berpenghasilan. Kondisi seperti menuntut kami sebagai istri untuk dapat melakukan aktivitas produktif agar dapat membiayai kebutuhan seharihari yang mutlak harus terpenuhi (wawancara, Pebruari 2012)

Melihat kenyataan tersebut peran ganda istri nelayan sangat produktif dalam memberi kontribusi pendapatn keluarga. Perubahan peran istri nelayan yang seringkali dianggap kontoversial, namun ternyata menyimpang arti yang lebih dalam, dengan bekerjanya istri sebagai pencari nafkah (ekonomi publik) si istri dapat mempunyai penghasilan sendiri yang dapat mengatasi kebutuhan ekonomi keluarga.

\section{b. Faktor Lingkungan}

Aktivitas istri nelayan untuk bekerja pada publik produktif sangat ditunjang oleh kondisi lingkungan tempat tinggal mereka yang berdiam di wilayah pesisir. Pada masyarakat nelayan seperti halnya di Kelurahan Lapulu, laut pada dasarnya merupakan sumber kekayaan alam yang tak ternilai harganya bagi manusia. Hal ini berkaitan dengan keberadaan di dalam laut senantiasa terkandung berbagai sumber alam yang dapat digunakan sebagai sarana untuk pemenuhan kelangsungan hidupnya. Artinya pontensi sumberdaya yang ada di dalam laut itu tidak akan berarti jika tidak ada uluran tangan manusia untuk memberi arti terhadapnya.Karena itulah potensi yang demikian itu akan bernilai apabila manusia berusaha untuk memanfaatkannya, dengan demikian untuk mengembangkan dan penggalian sumberdaya laut yang tersedia itu diperlukan adanya sumberdaya manusia yang terampil.

Ketersediaan sumberdaya laut untuk dikelola, memberi peran istri nelayan untuk bekerja disektor ekonomi publik. Berbagai jenis hasil laut dapat diolah menjadi bahan makanan yang mempunyai nilai jual yang tinggi, hasil tangkapan nelayan yang tidak dapat dijual dalam bentuk segar diolah menjadi ikan asin. Terdapatnya beberapa industri perusahaan pengolahan ikan disekitar wilayah Kelurahan Lapulu membuka peluang mereka untuk menjadi tenaga kerja di perusahaan tersebut.

\section{c. Kemandirian dan aktualisasi diri \\ Kemampuan istri nelayan dengan bekerja di ekonomi publik sudah dapat mengatasi}

ketergantungan hidup pada suami, mereka bebas mengatur keuangan tanpa meminta bantuan kepada suami, misalnya dalam pembelian perabot, alat-alat dapur, ongkos sekolah anak-anak, dan kebutuhankebutuhan lainnya. Kemandirian dalam mengatur keuangaan rumah tangga membuat si istri percaya diri dan berani mengambil keputusan.

Kemandirian istri nelayan yang dapat memenuhi kebutuhan rumah tangganya tanpa membebani suami, walaupun tanggungjawab sepenuhnya dalam mencari nafkah ada pada suami. Pekerjaan suami sebagai nelayan yang pendapatannya tidak menentu sangat mendukung apabila istri produktif di sektor ekonomi publik, itu pula yang menyebabkan istri-istri nelayan di Kelurahan Lapulu $90 \%$ bekerja diberbagai publik produktif, bukan hanya sekedar untuk membantu ekonomi keluarga, akan tetapi lebih dari itu untuk kemandirian dalam mengaktualisasikan diri dalam keluarga dan masyarakat.

Kebebasan wanita untuk dapat memajukan dirinya sebagai individu, ternyata juga untuk dapat memerankan secara optimal sisi lain identitas kodratinya yang tergantung pada lingkungannya (suami dan anaknya). Itu berarti kebebasan wanita adalah konteks kesadaran akan keterikatan dirinya dengan suami anak-anak dan orang-orang disekitarnya. Menurut istri-istri nelayan setempat bahwa, mendapatkan uang dari hasil bekerja baik melakukan pengolahan ikan, penjualan ikan, ataupun bekerja sebagai buruh pada perusahaan pengolahan ikan, menimbulkan perasaan senang karena mampu mengaktualisasikan diri seperti mampu mengikuti arisan baik di lingkungan keluarga maupun arisan antar tetangga, mampu mengisi amplop apabila ada keluarga atau tetangga yang melakukan pesta, maupun menyumbang apabila ada keluarga yang berduka dan selain sebagainya.

\section{d. Sosialisasi dan komunikasi}

Aktivitas istri nelayan di luar rumah memberi peluang untuk mereka dapat bersosialisasi dan berkomunikasi dengan masyarakat luas. Sebagai ibu rumah tangga tentunya mempunyai perasaan jenuh dan tertekan apabila hanya melakukan pekerjaan domestik, keberadaan mereka di arena publik mampu menciptakan jaringan sosial serta memberi kesempatan untuk saling beriteraksi baik sesama rekan kerja maupun antar pedagang dan kelompok.

Bekerja di ekonomi publik memberi kebebasan istri-istri nelayan untuk berinteraksi dengan masyarakat luar. Adanya dukungan dari suami menghilangkan perasaan tertekan dan bebas dalam beraktivitas, walaupun sudah bebas dari perasaan tertekan mereka senantiasa jujur dalam bertindak dan menjaga kehormatan suami sebagai kepala rumah tangga. Sebagai makhluk sosial, wanita nelayan membutuhkan interaksi dengan dunia luar untuk memudahkan mereka beraktivitas dan berkomunikasi 
dengan masyarakat di lingkungannya, baik yang berhubungan dengan relasi kerja maupun sesama pelaku ekonomi publik.

\section{Kontribusi Pendapatan Istri Nelayan dalam Meningkatkan Ekonomi Keluarga.}

Kontribusi penghasilan wanita pesisir, terhadap pemenuhan kebutuhan rumah tangga cukup besar. Dominasi wanita pesisir dalam pengelolaan keuangan keluarga sudah menjadi keharusan, sebagai mekanisme sosial yang konsektual dengan usaha perikanan. Menurut Sayogyo (1983), peran wanita dalam rumahtangga berkaitan erat dengan telaah pekerjaan yang dilakukan dalam rumah tangga. Perannya dalam mencari nafkah dapat dilihat dari curahan jam kerja untuk menghasilkan pendapatan. Dengan demikian kontribusi wanita tidak dapat diabaikan begitu saja.

Berdasarkan jenis usaha yang dilakukan wanita nelayan terlihat adanya perbedaan kontribusi dari berbagai jenis usaha yang dikelolah. Pendapatan dari istri nelayan diperoleh dari hasil berbagai jenis usaha yang dilakukannya untuk mecukupi kebutuhan rumahtangga. Istri nelayan pengolah ikan dan rumput laut, berdagang ikan dan bekerja di industri pengolahan serta usaha lainnya. Aktifitas pengolahan ikan dan rumput laut dilakukan tergantung dari ada atau tidaknya aktifitas melaut yang dilakukan oleh nelayan serta ada tidaknya hasil tangkapan. Sementara wanita nelayan yang berjualan atau berdagang ikan asin dan mereka yang menjadi buruh pada perusahaan industri pengolahan ikan aktifitasnya dilakukan setiap hari.

Besar kecilnya pendapatan nelayan pengolah ikan dan pedagang ikan sangat tergantung sekali kepada besar kecilnya hasil tangkapan sebagai bahan, dimana hasil tangkapan sangat tergantung sekali kepada keadaan cuaca. Jika musim ikan, istri nelayan yang melakukan pengolahan ikan untuk berbagai bahan makanan dan pembuat ikan asin memperoleh pendapatan yang cukup besar akan tetapi pada musim paceklik mereka hanya mengolah sedikit, bahkan sama sekali tidak melakukan pengolahan sehingga mereka juga tidak mempunyai pendapatan. Sedang bagi istri nelayan yang bekerja sebagai buruh industri pengolahan ikan akan mempunyai penghasilan lebih besar, apabila mereka lebih banyak melakukan lembur.

Kontribusi penghasilan istri nelayan berbedabeda sesuai dengan aktivitas pekerjaan yang dilakukan. Bagi istri nelayan yang melakukan pengolahan ikan menjadi bahan makanan seperti pembuatan abon, bakso dan kripik rumput laut berfluktuasi sesuai dengan ketersedian bahan yang akan diolah. Menurut ibu Linda bahwa, penghasilan yang diperoleh tidak tetap sesuai besarnya produksi yang dihasilkan, paling tinggi sekitar Rp. 1.200.000, sedang paling rendah sekitar Rp. 500.000 perbulan. Pendapatan suami sebagai nelayan paling tinggi sekitar Rp. 2.500.000, - dan paling rendah sekitar Rp.
700.000 perbulan. Jadi kalau digabung pendapatan saya dan suami tertinggi sekitar Rp. 3.700 .000 dan terendah Rp. 1.200.000 perbulan (wawancara, Pebruari 2012)

Sebagai pedagang ikan asin pendapatan mereka sangat tergantung oleh pasokan ikan asin yang masuk. Kalau musim penangkapan ikan dan cuaca panas maka pasoakan ikan asin lebih besar, sedang pada musim dimana nelayan tidak melaut, maka pasokan ikan asin berkurang sehingga daya jual menurun. Dari penuturan ibu Fatimah dimana pendapatan yang diperoleh memberi kontribusi yang lebih besar dari pendapatan suami dalam memenuhi kebutuhan rumah tangga. Kenyataan tersebut memperlihatkan bahwa peran wanita dalam memenuhi kebutuhan ekonomi keluarga bukan sekedar sebagai penghasilan tambahan, melainkan sudah menjadi pendapatan utama dalam keluarga.

Sementara bagi istri nelayan yang melakukan pekerjaan sebagai buruh pada perusahaan industri pengolahan ikan sifatnya lebih tetap, karena mereka mendapat gaji bulanan sebagai karyawan ditambah pula mereka mendapat fasilitas jaminan kesehatan untuk keluarganya dan tunjangan THR dari perusahaan. Sebagai karyawan mereka cukup signifikan kontribusi ekonomi yang diberikan kepada keluarga sangat membantu dalam memenuhi kebutuhan rumah tangga. Menurut mereka upah yang diperoleh sebulan sekitar Rp. 1.700.000, apabila mereka lembur. Tetapi apabila pasokan ikan kurang mereka tidak lembur, sehingga hanya mendapat penghasilan sesuai dengan pekerjaan rutin yang dilakukan setiap karyawan Penghasilan ini merupakan penghasilan tetap, selama menjadi mereka menjadi karyawan di Perusahaan tersebut. Kontribusi pendapatan istri nelayan yang bekerja di industri pengolahan ikan dapat mengatasi kesulitan ekonomi rumah tangga nelayan ketika suami mereka tidak melaut.

\section{SIMPULAN}

Berdasarkan hasil penelitian dan pembahasan yang telah diuraikan mengenai peran istri nelayan dalam sektor domestik dan ekonomi publik di Kelurahan Lapulu Kecamatan Abeli Kota Kendari, maka dapat diambil beberapa aspek yang menjadi kesimpulan bahwa: pertama, peran domestik istri nelayan merupakan aktivitas kesaharian mereka dalam mengurus rumah tangga. Peran reproduktif ini merupakan peran tadisi yang mencakup peran sebagi istri atau ibu yang mengurus suami dan anak, memasak, mencuci dan membersihakan rumah. Pada umumnya istri nelayan melakukan peran ini karena mereka tidak memiliki pembantu rumah tangga. Disamping itu peran domestik mencakup pula peran dalam mengasuh anak dan urusan pendidikan serta kewenangan istri dalam pengambilan keputusan dan urusan keuangan. Dalam aktivitas kemasyarakatan dan sosial, istri-istri nelayan di Kelurahan Lapulu 
sangat antusias mengikuti kegiatan yang diselenggarakan oleh ibu-ibu yang tergabung dalam organisasi PKK yang bertujuan untuk meningkatkan keterampilan dan sumberdaya manusia. Mereka juga terlibat dalam kelompok pengajian majelis ta'lim dan arisan yang diselenggarakan masyarakat setempat. Wadah ini memberi kesempatan kepada istri-istri nelayan untuk berinteraksi dan bersosialisasi dengan masyarakat di lingkungannya.

Dalam ekonomi publik peran istri nelayan, bukan hanya sekedar mengaktualisasikan diri dalam kesetaraan gender, melainkan peran produktif ini lebih pada pemenuhan kebutuhan ekonomi keluarga. Pendapatan suami sebagai nelayan yang tidak menentu menuntut mereka berperan untuk mencari nafkah tambahan. Berbagai usaha dan pekerjaan yang dilakukan istri-istri nelayan di Kelurahan Lapulu yang meliputi usaha pengolahan ikan menjadi berbagai produk makanan, pembuatan ikan asin, terasi dan perdagangan ikan asin serta sebagai buruh/karyawan pada perusahaan industri pengolahan ikan yang terdapat di Kelurahan Puday. Dari berbagai aktivitas ini mereka mendapatkan income untuk membantu memenuhi kebutuhan rumah tangga.

Kedua, berbagai faktor yang menyebabkan istri nelayan mengambil peran dalam sektor ekonomi publik terakait dengan rendahnya pendapatan yang diperoleh suami sebagai nelayan tidak menentu. Keberadaan mereka di wilayah pesisir mendukung para istri nelayan melakukan aktivitas dalam berbagai sumberdaya laut, keinginan untuk mandiri dalam berpenghasilan menjadikan istri tidak tergantung sepenuhnya pada penghasilan suami, demikian pula kebebasan dalam mengaktualisasikan diri serta kebutuhan dalam bersosialisasi dan berkomunikasi dengan masyarakat luar merupakan kecenderungan istri-istri nelayan untuk beraktivitas di rana ekonomi publik.

Ketiga, peran istri nelayan yang bekerja di sektor ekonomi publik telah memberi kontribusi yang cukup signifikan dalam meningkatkan pendapatan keluarga. Penghasilan yang diperoleh istri dengan melakukan berbagai kegiatan ekonomi publik dapat memenuhi berbagai kebutuhan hidup rumah tangga. Peran ini memberi pemasukan keluarga sehingga ekonomi keluarga akan meningkat dan kesejahteraan akan meningkat pula, dengan demikian ketahanan ekonomi mayarakat juga semakin meningkat, dimana peningkatan ini dicapai secara bertahap yaitu peningkatan konsumsi keluarga, peningkatan sandang dan papan keluarga.

Adapun saran yang dapat disampaikan dari penelitian ini, antara lain: pertama, peran istri nelayan disektor ekonomi publik di Kelurahan Lapulu Kecamatan Abeli Kota Kendari, merupakan salah satu usaha pemberdayaan wanita nelayan dalam meningkatkan kualitas sumberdaya manusia dalam meningkatkan ketahanan ekonomi dan tingkat kesejahteraan masyarakat pesisir. Upaya yang dilakukan istri nelayan ini perlu ditingkatkan secara terarah dan berkesinambungan, oleh karena itu perlu adanya upaya dari pemerintah setempat dan dinas terkait untuk terus melakukan pembinaan dan meningkatkan keterampilan sumberdaya manusia wanita nelayan agar dapat meningkatkan taraf hidup dan kesejahteraan masyarakat nelayan di Kelurahan Lapulu.

Kedua, peran serta Badan Keswadayaan Masyarakat (BKM) dalam membantu menfasilitasi kebutuhan modal usaha bagi masyarakat nelayan, khususnya istri-istri nelayan dalam mengembangkan usahanya merupakan suatu upaya yang dilakukan pemerintah untuk memperdayakan potensi yang dimiliki wanita nelayan. Untuk memaksimalkan dan mengefektifkan penyaluran dana yang di kelolah BKM perlu pengawasan dari pemerintah dan masyarakat agar tidak terjadi penyimpangan dan salah sasaran demi tercapainya kesejahteraan masyarakat nelayan. Demikian halnya sarana dan infrastruktur yang di bangun pemerintah dan instansi terkait di Kelurahan Lapulu yang berkaitan dengan aktivitas kenelayanan dengan tujuan untuk menfasilitasi dan memberi kemudahan untuk pengembangan usaha nelayan tidak dipergunakan semaksimal mungkin, sehingga sarana tersebut terkesan tidak memberi banyak manfaat bagi masyarakat disekitarnya. Oleh karena itu perlu dilakukan sosialisasi dan musyawarah kepada masyarakat nelayan setempat terkait dengan infrastruktur yang tersedia agar dimanfaatkan dan dipergunakan semaksimal mungkin untuk meningkatkan usaha dan pendapatan masyarakat nelayan.

\section{DAFTAR PUSTAKA}

Chusnul Hayat, 2006. Gender dan Perubahan Ekonomi : Peranan Perempuan Dalam Indistri Batik di Yogyakarta 1900-1965. Semarang: Fakultas Sastra UNDIP.

Dloyana Kusumah, 2010. Pembentukan Norma dan Nilai Baru Dalam Pranata Keluarga (Studi Tentang Peran Ganda Perempuan di Kelurahan Cibaduyut). Yogyakarta: Penerbit Kepel Press.

Fadlia vadlun Yotolembah Aminah, 2011. Makna Wanita Tentang Perubahan Peran

( Kajian disertasi wanita istri nelayan suku Kaili dalam perubahan peran dari domestik tradisional ke publik produktif). Palu: Media Litbang Sulteng IV :12-23 Juni.

Kusnadi, 2001. Pangamba' Kaum Perempuan Fenomenal: Pelopor dan Penggerak

Perekonomian Masyarakat Nelayan. Bandung: Humaniora Utama Press.

Muhammad Kurniawan, 2010. Etty Kereway Kiprah Perempuan Papua. Kompas Rabu 7 April 2010

Sajogyo, 1983. Peranaan Wanita dalam Pembangunan Masyarakat Desa.Jakarta: Rajawali Press. 
Raodah, 2010. Aktivitas Perekonomian Nelayan Bugis. Balai Pelestarian Sejarah dan Nilai Tradisional Makassar: Penerbit Dian Istana

Winarti, dkk. 2008. Peberdayaan Perempuan Pada Sektor Industri Kecil Dalam Mengatasi Ekonomi keluarga. Jakarta: Universitas Pendidikan Indonesia 